\title{
Effect of different seasons on some honey bee activities under Nasr City conditions - (Cairo) Egypt
}

\author{
Adel A. AL-Ayat, G. F. Abo Laban, Shehata, A. A., Hussain. E. \\ Plant Protection Department- Faculty of Agriculture - Al-Azhar University- Cairo
}

\begin{abstract}
This study was carried out at the apiary of the Plant Protection Department- Faculty of Agriculture - AlAzhar University- Cairo during year (2013\&2014). Colonies of carniolan $F_{1}$ hybrid were used. The results showed that the largest monthly mean of the sealed worker brood area (in. $\left.{ }^{2}\right)$ /colony recorded (370.0, 369.2 and 292.2) in spring for the colonies without traps (control), with fixed trap three days and without three days ( $3 \& 3$ ) consequently and colony with fixed traps, along the whole time of the investigation period, respectively. While the smallest monthly means of the sealed worker brood area $\left(\right.$ in. $\left.{ }^{2}\right) /$ colony recorded $(146.4,140.9$ and 121.3) in autumn for control and another two treatments, resp. Spring season is the best season for the monthly means of the stored pollen area $\left(\right.$ in. $\left.^{2}\right) /$ colony $(137.3,111.8$ and 88.8$)$ for control , and another two treatments resp. Whereas, the smallest monthly mean of the stored pollen area $\left(\mathrm{in} .{ }^{2}\right) /$ colony recorded $(28.2,22.2$, and 12.6) in autumn for control and another two treatments resp. The spring season is the best, where the monthly means of the stored honey area (in. $\left.{ }^{2}\right) /$ colony were $(600.0,480.2$ and 338.3) for control, and another two treatments, respectively. The smallest monthly means of the stored honey area (in. ${ }^{2}$ )/colony recorded (70.4, 65.0 and 44.6) in autumn for control and another two treatments resp. the other two seasons are ranked in between in the three activities. All data obtained were statistically analyzed and discussed.
\end{abstract}

Key words: honey bee activities, different seasons.

\section{Introduction}

Pollen and nectar are the natural major protein and carbohydrates sources of the honeybee colonies, they are very important and necessary for the development, worker brood area producing, strength, and healthy of the honeybee colony. A good relationship between nectar flow seasons and all honey bee activities and their products under suitable environmental conditions according to the role which say no pollen no bees. Colony development, reproduction, population size and food reserves are the major criteria to measure the success of honey bee colony surviving in different regions (Paxton and Echagarreta, 1997). They are affected by many environmental factors, (Harbo, 1986 and Chinh et al 2005). Pollen is the sole protein food of honey bee colony harvested by bee foragers in their natural environment. The presence of pollen in the nest is a prerequisite for normal colony development and first of all, for regular growth and development of the brood. Brood rearing is a major factor in apiary production and affected by colony feeding on nature pollen and nectar (Roman, 2006). In Egypt, many researchers studied honeybee activities \{(Khattab (1976), Abd Al-Fattah (1983), El-Wasseef (2002), Shawer et. al. (2003), Abd Al- Hady (2007), El-Feel, (2008), Zaref, 2008), and Shaheen, (2012)\}, under the condition of the different regions, but few investigations were carried out in Nasr city region. So, the aim of this study is monitoring some activities of honey bee colonies in rearing worker brood, gathering pollen, and producing honey under different seasons.

\section{Materials and Methods}

This study was carried out at apiary of Plant Protection Department, Faculty of Agriculture, AlAzhar University, Cairo, Egypt, during 2013- 2014.

1- Experiments design:

Twelve honey bee colonies (Carniolan $F_{1}$ hybrid) of the same strength, each colony consisted of four brood combs, two honey and pollen combs and headed by new mated queen sisters were prepared and divided as follow.

a. Each of four colonies provided by pollen traps, fixed at the hive entrance (permanent fixed traps) throughout the investigation period (treatment).

b. Each of another four colonies provided by pollen trap fixed at the hive entrance three days and removed three days consequently, (fixed traps $3 \& 3$ ) throughout the investigation period (treatment).

c. Four colonies without fixed pollen traps (control).

The bees in these tested colonies were allowed to free flight for collecting available nectar and pollen from cultivated sources as well as natural plants existed in this region.

2- Activities of honey bee colonies:

Activity measurements of the $F_{1}$ hybrid Carniolan colonies were investigated to evaluate the effect of 
different treatments under different seasons on the following parameters:

a. Worker brood areas $\left(\right.$ inch $\left.^{2}\right)$.

b. Pollen stored areas $\left(\right.$ inch $\left.^{2}\right)$.

c. Honey stored areas $\left(\right.$ inch $\left.^{2}\right)$.

These activities were measured at (13) day intervals, by using a langstroth frame divided into square inches.

Data were subjected to analysis of variance (ANOVA) using "COSTA" computer statistical program. Mean values were compared using Duncan's multiple range test (Duncan, 1955).

\section{Results and Discussions}

Monthly means of honeybee sealed worker brood areas (in. ${ }^{2}$ )/colony established at Nasr city during seasons of (2013\&2014) were measured. Data presented in Table (1) and figure (1), showed that the largest monthly means of the sealed worker brood area (in. $\left.{ }^{2}\right) /$ colony recorded $(370.0,369.2$ and 292.2) in spring for control and another two treatments resp. while the smallest monthly means of the sealed worker brood area recorded (146.4, 140.9 and 121.3) in autumn for control and another two treatments, resp. The monthly means of the sealed worker brood area recorded $(177.8,215.4$ and 223.0) in winter ranked the second order followed by the monthly means $(150.4,195.8$ and 204.5) in summer for control and another two treatments resp. From above mentioned data, it could be cleared that increasing of the monthly means of the sealed worker brood areas (in. ${ }^{2}$ )/colony during spring and winter seasons is due to absence of oriental hornet and presence of Eucalyptus flow where attacking of oriental hornet during autumn leads to decreasing of the monthly mean of the sealed worker brood area.

There were significant differences among the monthly means of sealed worker brood areas in different seasons for permanent fixed traps. While there were no significant differences between the means of winter and summer seasons for control, and fixed traps $3 \& 3$. On the other hand, there were significant difference between these means for the control and fixed traps $3 \& 3$ in all while there was significant difference between above mentioned and means of permanent fixed traps colonies in all seasons. As respect to effect of putting trap on the colony, the data in the same table show that the smallest monthly means of the sealed worker brood area $\left(\right.$ in. $\left.{ }^{2}\right) /$ colony recorded (general mean 185.4) in the colony with fixed trap throughout the investigated period (permanent) while, the largest one recorded in control (236.0). The general monthly mean of the sealed worker brood area for fixed traps $3 \& 3$ was $\left(230.3 \mathrm{in.}^{2}\right)$. Statistical analysis gave no difference between general monthly mean of the sealed worker brood area for control and fixed traps $3 \& 3$. While there was a significant difference between the mean of the permanent fixed traps treatment and each of control and fixed traps 3\&3. Serag El-Dein, (1991 \& 2004) reported that in Kafr El-Sheikh region, for Carniolan race colonies, the highest average of sealed worker brood area was found during May and July, while the lowest area was found during November. Taha, (2005) found that, for Carniolan race colonies, the largest mean worker sealed brood area (289.7 \& 290.04 in $^{2} / 12$ days/colony) was observed at clover blossoming period in two observation years, respectively. Abd AlHady, (2007) reported that, for Carniolan race colonies, the highest rate of worker brood rearing was during spring, (37.28\%), followed by summer, (25.92\%), winter, $(21.24 \%)$ and autumn, (15.56\%). 
Table 1. Monthly means of honeybee sealed worker brood areas (in. ${ }^{2}$ )/colony established at Nasr city during season of (2013\&2014).

\begin{tabular}{|c|c|c|c|c|c|c|c|c|c|c|c|c|c|c|c|c|}
\hline \multirow[t]{2}{*}{ Season } & \multirow[t]{2}{*}{ Month } & \multicolumn{4}{|c|}{ Permanent fixed traps } & \multirow[t]{2}{*}{ Mean } & \multicolumn{4}{|c|}{ Fixed traps $3 \& 3$} & \multirow[t]{2}{*}{ Mean } & \multirow[b]{2}{*}{$\mathrm{R} 1$} & \multicolumn{3}{|c|}{ Control } & \multirow[t]{2}{*}{ Mean } \\
\hline & & R1 & R2 & R3 & $\mathrm{R} 4$ & & $\mathrm{R} 1$ & R2 & R3 & $\mathrm{R} 4$ & & & $\mathrm{R} 2$ & R3 & $\mathrm{R} 4$ & \\
\hline \multirow[t]{4}{*}{ Autumn } & Sep. & 100 & 90 & 105 & 90 & 96.25 & 113 & 110 & 115 & 117 & 113.8 & 115 & 110 & 117.5 & 110 & 113.1 \\
\hline & Oct. & 127 & 120 & 133 & 127 & 126.8 & 132.5 & 147.5 & 145 & 145 & 142.5 & 165 & 147 & 135 & 147.5 & 148.6 \\
\hline & Nov. & 134 & 145 & 150 & 135 & 141.0 & 160 & 170 & 166 & 170 & 166.5 & 180 & 170 & 170 & 190 & 177.5 \\
\hline & Mean & 120.3 & 118.3 & 129.3 & 117.3 & $121.3 \mathrm{Db}$ & 135.2 & 142.5 & 142.0 & 144.0 & $140.9 \mathrm{Ca}$ & 153.3 & 142.3 & 140.8 & 149.2 & $146.4 \mathrm{Ca}$ \\
\hline \multirow[t]{4}{*}{ Winter } & Dec. & 160 & 166 & 182 & 160 & 167.0 & 190 & 200 & 195 & 200 & 196.3 & 200 & 210 & 205 & 210 & 206.3 \\
\hline & Jan. & 170 & 170 & 175 & 170 & 171.3 & 200 & 210 & 200 & 210 & 205.0 & 205 & 210 & 210 & 220 & 211.3 \\
\hline & Feb. & 200 & 205 & 190 & 185 & 195.0 & 250 & 260 & 230 & 240 & 245.0 & 255 & 266 & 240 & 245 & 251.5 \\
\hline & Mean & 176.7 & 180.3 & 182.3 & 171.7 & $177.8 \mathrm{Bb}$ & 213.3 & 223.3 & 208.3 & 216.7 & $215.4 \mathrm{Ba}$ & 220.0 & 228.7 & 218.3 & 225.0 & $223.0 \mathrm{Ba}$ \\
\hline \multirow[t]{4}{*}{ Spring } & Mar. & 270 & 288 & 260 & 255 & 268.3 & 370 & 380 & 310 & 300 & 340.0 & 330 & 340 & 315 & 300 & 321.3 \\
\hline & Apr. & 300 & 310 & 303 & 280 & 298.3 & 380 & 390 & 350 & 340 & 365.0 & 380 & 380 & 355 & 350 & 366.3 \\
\hline & May & 315 & 320 & 310 & 295 & 310.0 & 410 & 422 & 388 & 390 & 402.5 & 455 & 435 & 400 & 400 & 422.5 \\
\hline & Mean & 295.0 & 306.0 & 291.0 & 276.7 & $292.2 \mathrm{Ab}$ & 386.7 & 397.3 & 349.3 & 343.3 & 369.2Aa & 388.3 & 385.0 & 356.7 & 350.0 & $370.0 \mathrm{Aa}$ \\
\hline \multirow[t]{4}{*}{ Summer } & Jun. & 230 & 222 & 225 & 205 & 220.5 & 280 & 260 & 240 & 250 & 257.5 & 290 & 265 & 255 & 266 & 269.0 \\
\hline & Jul. & 160 & 150 & 135 & 125 & 142.5 & 210 & 200 & 175 & 220 & 201.3 & 220 & 200 & 188 & 225 & 208.3 \\
\hline & Aug. & 80 & 95 & 90 & 88 & 88.3 & 130 & 120 & 125 & 140 & 128.8 & 137 & 125 & 133 & 150 & 136.3 \\
\hline & Mean & 156.7 & 155.7 & 150.0 & 139.3 & $150.4 \mathrm{Cb}$ & 206.7 & 193.3 & 180.0 & 203.3 & $195.8 \mathrm{Ba}$ & 215.7 & 196.7 & 192.0 & 213.7 & $204.5 \mathrm{Ba}$ \\
\hline \multicolumn{2}{|c|}{ General mean } & 187.2 & 190.1 & 188.2 & 176.3 & $185.4 \mathrm{~B}$ & 235.5 & 239.1 & 219.9 & 226.8 & $230.3 \mathrm{~A}$ & 244.3 & 238.2 & 227.0 & 234.5 & $236.0 \mathrm{~A}$ \\
\hline
\end{tabular}




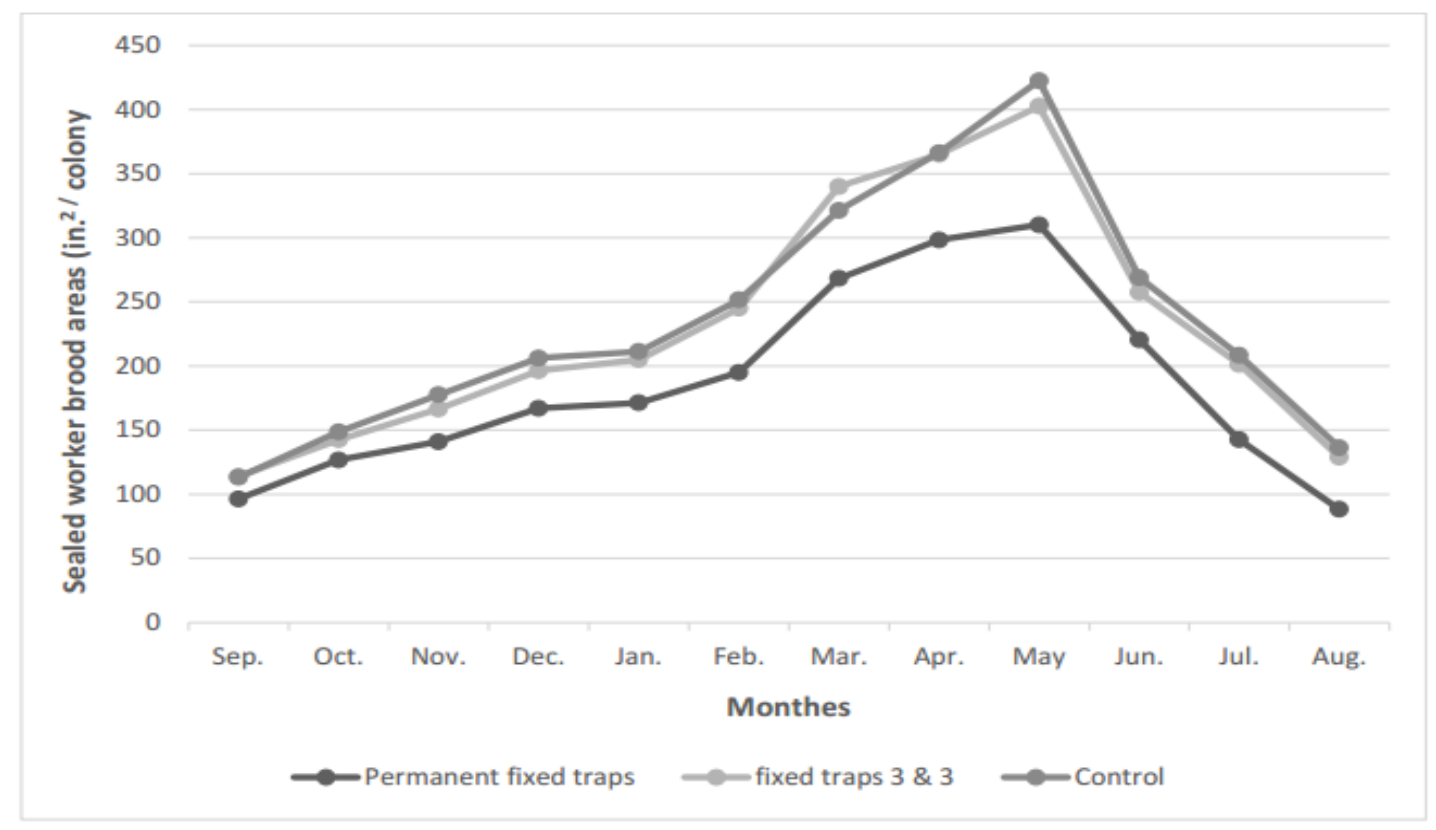

Fig.1. Mean of sealed worker brood areas (in. $\left.{ }^{2}\right)$ per honey bee colony established at Nasr city during seasons of (2013\&2014).

\subsection{Storing pollen area. \\ Monthly means of stored pollen areas (in. ${ }^{2}$ ) by honeybee colonies established at Nasr city during seasons of (2013\&2014).}

Data presented in Table (2) and Figure (2). show that the activity started in Sep. where the recorded pollen area per colony was (17.3, 15.3 and 4.0) for control, fixed traps $3 \& 3$ and the colony with permanent fixed trap through September, resp. the monthly activity increased gradually to record peak of activity during May (152.5, 124.3 and 101.8) for control, fixed traps $3 \& 3$ and the colony with permanent fixed traps, resp. The activity decreased gradually to give less stored pollen area (in. ${ }^{2}$ ) /colony in August (11.3, 6.3 and 0.0) for control, fixed traps $3 \& 3$ and the colony with permanent fixed traps, resp. As regard to the effect of the season on the monthly means of the stored pollen area (in. $\left.{ }^{2}\right) /$ colony, it could be cleared that spring season is the best season for the monthly means of the stored pollen area (in. $\left.{ }^{2}\right) /$ colony (137.3, 111.8 and 88.8) for control, colony with fixed trap (3\&3) consequently fixed traps along the whole time of the investigation. The smallest monthly means of the stored pollen area (in. $\left.{ }^{2}\right) /$ colony recorded (28.2, 22.2, and 12.6) in autumn for control and another two treatments resp. The monthly means of the stored pollen area $\left(\right.$ in. $\left.{ }^{2}\right) /$ colony recorded in winter $(80.7,66.3$ and 45.8) ranked the second order followed by the monthly means recorded (65.0, 48.2 and 29.1) in summer for control and another two treatments resp. Statistically there were significant differences among the monthly means in the different seasons either for control and treatments.

From above mentioned data it could be concluded that, increasing of the monthly means of the stored pollen area (in. ${ }^{2}$ )/colony during spring and winter seasons is due to the same reasons mentioned above in sealed brood means. As respect to the effect of putting trap on the colony, the data in the same table show that the smallest monthly means of the stored pollen area $\left(\right.$ in. $\left.{ }^{2}\right) /$ colony recorded (general mean 44.1 ) in the colony with permanent trap throughout the investigated period while the largest one (general mean 77.8) recorded in control. The obtained results are in agreement with those of Hussein, (1982) for Carniolan race colonies, who mentioned that a significant effect on pollen gathering activity was detected after feeding of colonies during the dearth season (December), while non-significant correlation was noticed during active season (March and April). Shawer et al. (2003) in Kafr El-Sheikh revealed that the highest number of incoming workers carrying pollen/colony/minute and the largest stored pollen area throughout the blooming seasons of citrus, clover and cotton was observed in colonies moved to food sourcesrich areas. The highest number of incoming workers carrying pollen/colony/minute and the largest stored pollen area were found in May (the blooming season of clover), followed by July and August (cotton season). Zeedan, (2002) revealed that under the environmental conditions of Giza region, gathering and storing pollen began slightly during January recorded 2178.5 pollen cells/colony, representing $5.7 \%$ and increased during February $6.5 \%$ and reached its maximum rate of 
gathering pollen during August $12.8 \%$ then these amounts were declined gradually to its minimum value stored pollen during December, $5.0 \%$ of the total stored pollen. He reported that the highest rate of stored pollen recorded in the summer season $(4582.2$ cells/col. represented $36.0 \%)$. The lowest rate recorded in winter (2113.3 cells/col. represented $16.6 \%)$.

Table 2. Monthly means of stored pollen areas (in. ${ }^{2}$ ) /honeybee coloney established at Nasr city during seasons of (2013\&2014).

\begin{tabular}{|c|c|c|c|c|c|c|c|c|c|c|c|c|c|c|c|c|}
\hline \multirow{2}{*}{ Season } & \multirow{2}{*}{ Month } & \multicolumn{5}{|c|}{ Permanent fixed traps Mean } & \multicolumn{4}{|c|}{ Fixed traps $3 \& 3$} & \multirow[t]{2}{*}{ Mean } & \multicolumn{4}{|c|}{ Control } & \multirow[t]{2}{*}{ Mean } \\
\hline & & $\overline{\mathrm{R} 1}$ & $\mathrm{R} 2$ & R3 & $\mathrm{R} 4$ & & $\mathrm{R} 1$ & $\mathrm{R} 2$ & R3 & R4 & & R1 & $\mathrm{R} 2$ & R3 & R4 & \\
\hline & Sep. & 5 & 4 & 2 & 5 & 4.0 & 10 & 18 & 13 & 20 & 15.3 & 20 & 18 & 16 & 15 & 17.3 \\
\hline \multirow[t]{2}{*}{ Autumn } & Oct. & 10 & 10 & 7 & 12 & 9.8 & 20 & 18 & 14 & 20 & 18.0 & 25 & 27 & 30 & 27 & 27.3 \\
\hline & Nov. & 25 & 24 & 20 & 27 & 24.0 & 30 & 31 & 32 & 40 & 33.3 & 30 & 37 & 48 & 45 & 40.0 \\
\hline \multirow[t]{2}{*}{ Mean } & & 13.3 & 12.7 & 9.7 & 14.7 & $12.6 \mathrm{Dc}$ & 20.0 & 22.3 & 19.7 & 26.7 & $22.2 \mathrm{Db}$ & 25.0 & 27.3 & 31.3 & 29.0 & $28.2 \mathrm{Da}$ \\
\hline & Dec. & 35 & 36 & 37 & 35 & 35.8 & 55 & 57 & 57 & 48 & 54.3 & 60 & 65 & 60 & 65 & 62.5 \\
\hline \multirow[t]{2}{*}{ Winter } & Jan. & 44 & 45 & 47 & 42 & 44.5 & 66 & 60 & 67 & 66 & 64.8 & 80 & 82 & 83 & 80 & 81.3 \\
\hline & Feb. & 52 & 55 & 60 & 62 & 57.3 & 85 & 72 & 84 & 79 & 80.0 & 100 & 100 & 94 & 99 & 98.3 \\
\hline \multicolumn{2}{|l|}{ Mean } & 43.7 & 45.3 & 48.0 & 46.3 & $45.8 \mathrm{Bc}$ & 68.7 & 63.0 & 69.3 & 64.3 & $66.3 \mathrm{Bb}$ & 80.0 & 82.3 & 79.0 & 81.3 & $80.7 \mathrm{Ba}$ \\
\hline \multirow{3}{*}{ Spring } & Mar. & 70 & 75 & 75 & 72 & 73.0 & 100 & 95 & 102 & 97 & 98.5 & 115 & 120 & 125 & 115 & 118.8 \\
\hline & Apr. & 85 & 95 & 97 & 90 & 91.8 & 110 & 105 & 117 & 119 & 112.8 & 140 & 140 & 145 & 138 & 140.8 \\
\hline & May & 95 & 105 & 107 & 100 & 101.8 & 130 & 120 & 127 & 120 & 124.3 & 150 & 155 & 155 & 150 & 152.5 \\
\hline \multirow[t]{2}{*}{ Mean } & & 83.3 & 91.7 & 93.0 & 87.3 & 88.8Ac & 113.3 & 106.7 & 115.3 & 112.0 & $111.8 \mathrm{Ab}$ & 135.0 & 138.3 & 141.7 & 134.3 & $137.3 \mathrm{Aa}$ \\
\hline & Jun. & 60 & 65 & 57 & 73 & 63.8 & 100 & 88 & 95 & 80 & 90.8 & 120 & 115 & 120 & 110 & 116.3 \\
\hline \multicolumn{2}{|c|}{ Summer Jul. } & 25 & 16 & 27 & 26 & 23.5 & 50 & 45 & 55 & 40 & 47.5 & 65 & 60 & 75 & 70 & 67.5 \\
\hline & Aug. & 0 & 0 & 0 & 0 & 0.0 & 10 & 5 & 10 & 0 & 6.3 & 15 & 10 & 10 & 10 & 11.3 \\
\hline \multicolumn{2}{|l|}{ Mean } & 28.3 & 27.0 & 28.0 & 33.0 & $29.1 \mathrm{Cc}$ & 53.3 & 46.0 & 53.3 & 40.0 & $48.2 \mathrm{Cb}$ & 66.7 & 61.7 & 68.3 & 63.3 & $65.0 \mathrm{Ca}$ \\
\hline \multicolumn{2}{|c|}{ General mean } & 42.2 & 44.2 & 44.7 & 45.3 & $44.1 \mathrm{C}$ & 63.8 & 59.5 & 64.4 & 60.8 & $62.1 \mathrm{~B}$ & 76.7 & 77.4 & 80.1 & 77.0 & $77.8 \mathrm{~A}$ \\
\hline
\end{tabular}




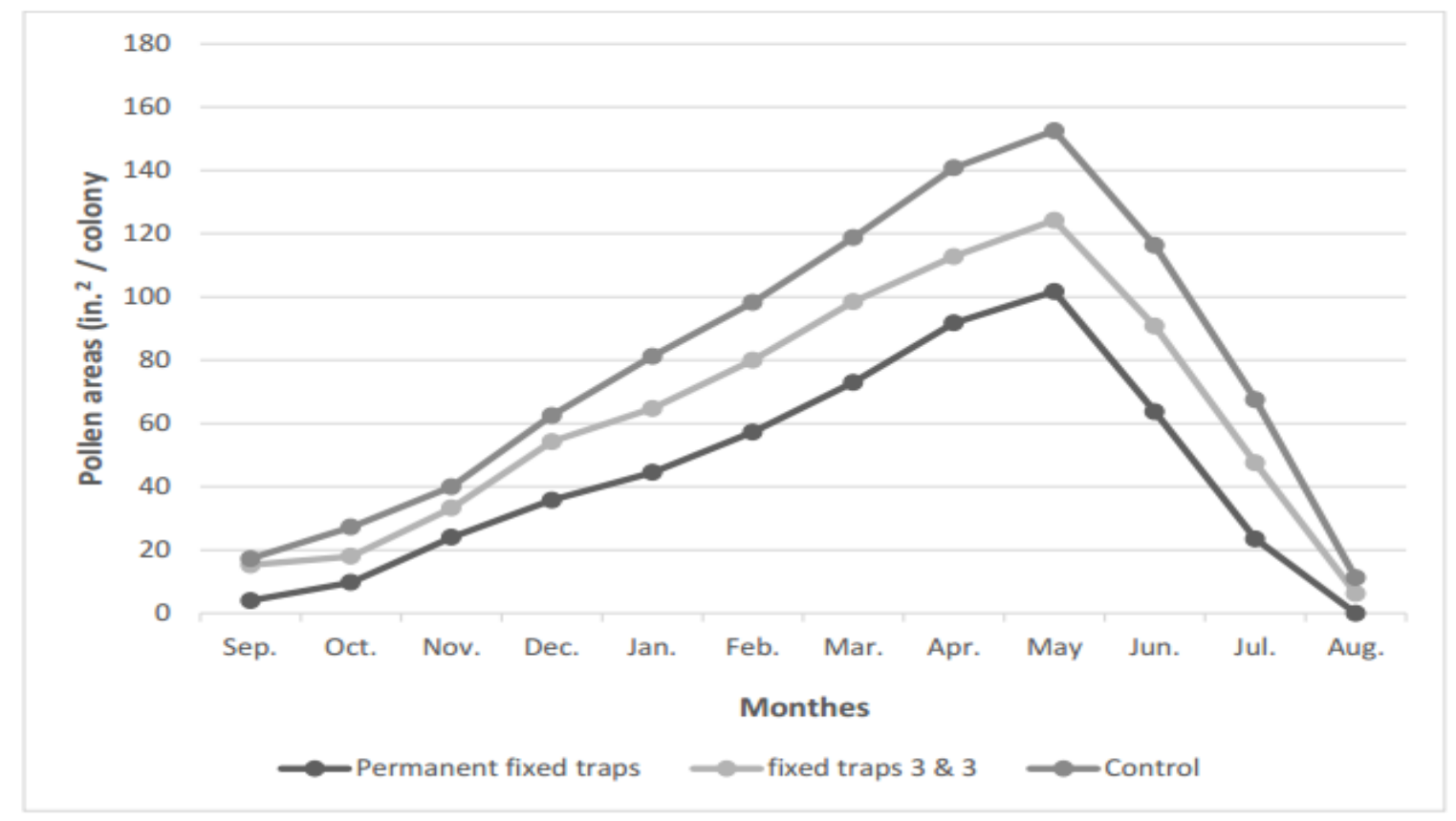

Fig :( 2). Monthly means of stored pollen areas $\left(\right.$ in. $\left.^{2}\right) /$ honeybee coloney established at Nasr city during seasons of (2013\&2014).

\subsection{Storing honey area.}

Monthly means of honey bee stored honey area (in. ${ }^{2}$ ) /colony established at Nasr city during season of $(2013 \& 2014)$.

Data presented in Table (3) and Figure (3), show that the recorded area per colony was $(38.6,32.5$ and 20.0) for control, fixed traps $3 \& 3$ and the colony with permanent fixed trap through September, resp. The monthly activity increased gradually to record peak of activity during Jun. (837.5, 747.5 and 432.5) for control, fixed traps $3 \& 3$ and the colony with permanent fixed trap, resp. The activity decreased gradually to give less stored honey area (in. $\left.{ }^{2}\right)$ /colony in August (51.25, 45.0 and 25.0) for control, fixed traps $3 \& 3$ and the colony with permanent fixed trap, resp. nearly to that gained in Sep. It could be noticed that the reduction of the stored honey area (in. $\left.{ }^{2}\right) /$ colony is due to attacking of oriental hornet. As regard to the effect of the season on the monthly means of the stored honey area $\left(\right.$ in. $\left.{ }^{2}\right) /$ colony, it is clear that spring season is the best season on the monthly means of the stored honey area (in. $\left.{ }^{2}\right) /$ colony (600.0, 480.2 and 338.3) for control, colony with fixed trap (3\&3) and colony with permanent fixed trap, respectively. The smallest monthly means of the stored honey area recorded (70.4, 65.0 and 44.6) in autumn for control and another two treatments resp. The monthly means of the stored honey area recorded in summer
(319.6, 286.7 and 165.4) for control and another two treatments resp. Which ranked the second order followed by the monthly means recorded (167.1, 147.9 and 106.7) in winter for control and another two treatments resp. Statistically there were significant differences among the monthly means in the different seasons either in control or treatments. From above mentioned data, increasing of the monthly means of the stored honey area (in. $\left.{ }^{2}\right) /$ colony during spring and summer seasons is due to the same reasons mentioned before that. As respect to the effect of putting trap on the colony, the data in the same table show that the smallest monthly mean of the stored honey area $\left(\right.$ in. $\left.{ }^{2}\right) /$ colony recorded (general mean 163.8) in the colony with permanent trap throughout the investigated period while the largest one recorded in control (general mean 289.3) while fixed traps $3 \& 3$ days gained (244.9). Abou ElEnain, (2002) summarized that under Alexandria local conditions, the average honey yield per colony was 3.0, 6.2 and $8.5 \mathrm{~kg}$. /colony for the Egyptian, Carniolan and the hybrid, respectively. Most of honey harvested during clover season was in June and during cotton season in September. Helal et al. (2003) stated that, the highest amount of honey throughout the three different blooming seasons of citrus, clover and cotton was obtained from colonies moved to food sources-rich area. The largest yield of honey was collected during May 
(clover season), followed by April (citrus blooming period). Abdel-Rahman, (1998 \& 2004), stated that in Assiut region the largest average honey yield, for
Carniolan race colonies, was obtained from cotton plants (July), followed by clover season (May).

Table 3. Monthly means of honey bee stored honey area (in. ${ }^{2}$ ) /colony established at Nasr city during seasons of (2013\&2014).

\begin{tabular}{|c|c|c|c|c|c|c|c|c|c|c|c|c|c|c|c|c|}
\hline \multirow[t]{2}{*}{ eason } & \multirow[t]{2}{*}{ Month } & \multicolumn{4}{|c|}{ Permanent fixed traps } & \multirow[t]{2}{*}{ Mean } & \multicolumn{4}{|c|}{ Fixed traps $3 \& 3$} & \multirow[t]{2}{*}{ Mean } & \multicolumn{4}{|c|}{ Control } & \multirow[t]{2}{*}{ Mean } \\
\hline & & $\bar{R} 1$ & $\mathrm{R} 2$ & $\mathrm{R} 3$ & $\mathrm{R} 4$ & & $\mathrm{R} 1$ & $\mathrm{R} 2$ & $\mathrm{R} 3$ & $\mathrm{R} 4$ & & $\mathrm{R} 1$ & $\mathrm{R} 2$ & $\mathrm{R} 3$ & 24 & \\
\hline \multirow[t]{3}{*}{ utumn } & p. & 20 & 20 & 20 & 20 & 20 & 30 & 40 & 32.5 & 27.5 & 2.5 & 37.5 & 40 & 37 & 40 & \\
\hline & $\overline{\text { Oct. }}$ & 30 & $\overline{50}$ & 35 & $\overline{8}$ & & 50 & 100 & 60 & 80 & 2.5 & $\overline{70}$ & 75 & 60 & 85 & \\
\hline & & 50 & 60 & 55 & & & 80 & 105 & 75 & 10 & 0.0 & 100 & 100 & 90 & 11 & 00.0 \\
\hline \multicolumn{2}{|l|}{ Mean } & 33.3 & 43.3 & 36.7 & 65.0 & 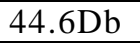 & 3.3 & 1.7 & 55.8 & 69.2 & $.0 \mathrm{Da}$ & 69.2 & 71.7 & 2.3 & 78.3 & $\mathrm{a}$ \\
\hline \multirow[t]{3}{*}{ Vinter } & ec. & 80 & 100 & 75 & on & & 100 & 120 & 110 & 13 & 0 & 135 & 140 & 130 & 140 & 36.3 \\
\hline & & 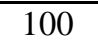 & 115 & 100 & 10 & & 45 & 155 & 35 & 14 & .0 & 160 & 175 & 175 & 15 & .3 \\
\hline & & 125 & 33 & 127 & $\overline{140}$ & & 170 & 190 & 180 & 195 & 183.8 & 190 & 220 & 210 & $1 / 5$ & .8 \\
\hline \multicolumn{2}{|l|}{ Iean } & 101.7 & 116 & 100.7 & 108.3 & $106.7 \mathrm{Cc}$ & 138.3 & 155.0 & 141.7 & 156.7 & $147.9 \mathrm{Cl}$ & 161.7 & 178.3 & 171. & 156.7 & 167.1 \\
\hline \multirow[t]{3}{*}{ oring } & ar. & 90 & 280 & 285 & 260 & 278.8 & 322 & 340 & 355 & 350 & 341.8 & 440 & 485 & 475 & 430 & 457.5 \\
\hline & Apr. & 55 & 405 & 360 & 385 & 8.8 & 585 & 580 & 590 & 500 & 563.8 & 600 & 655 & 660 & 610 & 31.3 \\
\hline & & 355 & 360 & 335 & 380 & 357.5 & 550 & 565 & 560 & 465 & 535.0 & 680 & 740 & 720 & 705 & 711.3 \\
\hline \multicolumn{2}{|l|}{ Mean } & 6. & 348. & 26. & 41. & $3 t$ & 485. & 495.0 & 501.7 & 438.3 & $80.2 \mathrm{Al}$ & 573.3 & 626.7 & 618.3 & 581.7 & $600.0 \mathrm{Aa}$ \\
\hline \multicolumn{2}{|c|}{ Immer Jun. } & 400 & 420 & 465 & 445 & 432.5 & 755 & 765 & 780 & 690 & 747.5 & 875 & 800 & 890 & 785 & 837.5 \\
\hline & Jul. & 30 & 30 & 55 & 40 & 38.8 & 75 & 70 & 85 & 40 & 67.5 & 90 & 70 & 60 & 60 & 70.0 \\
\hline & & 20 & 20 & 30 & 30 & 25.0 & 50 & 50 & 50 & 30 & 45.0 & 50 & 55 & 50 & 50 & 51.25 \\
\hline \multicolumn{2}{|l|}{ ean } & n & & 83. & 71 & $55.4 \mathrm{~B}$ & 293. & 295. & 305 & 253 & $86.7 \mathrm{E}$ & 338 & 308.3 & 333 & 98.3 & $319.6 \mathrm{Ba}$ \\
\hline \multicolumn{2}{|c|}{ eneral mean } & 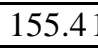 & 00.1 & & & $3.8 \mathrm{C}$ & 242 & 256. & 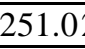 & 229.4 & 244.9 & 285. & 296.3 & 296 & 18.8 & $289.3 \mathrm{~A}$ \\
\hline
\end{tabular}

Means in the same row or column with the same small or capital letters do not differ significantly according to Duncan's multiple range test at $5 \%$ probability.

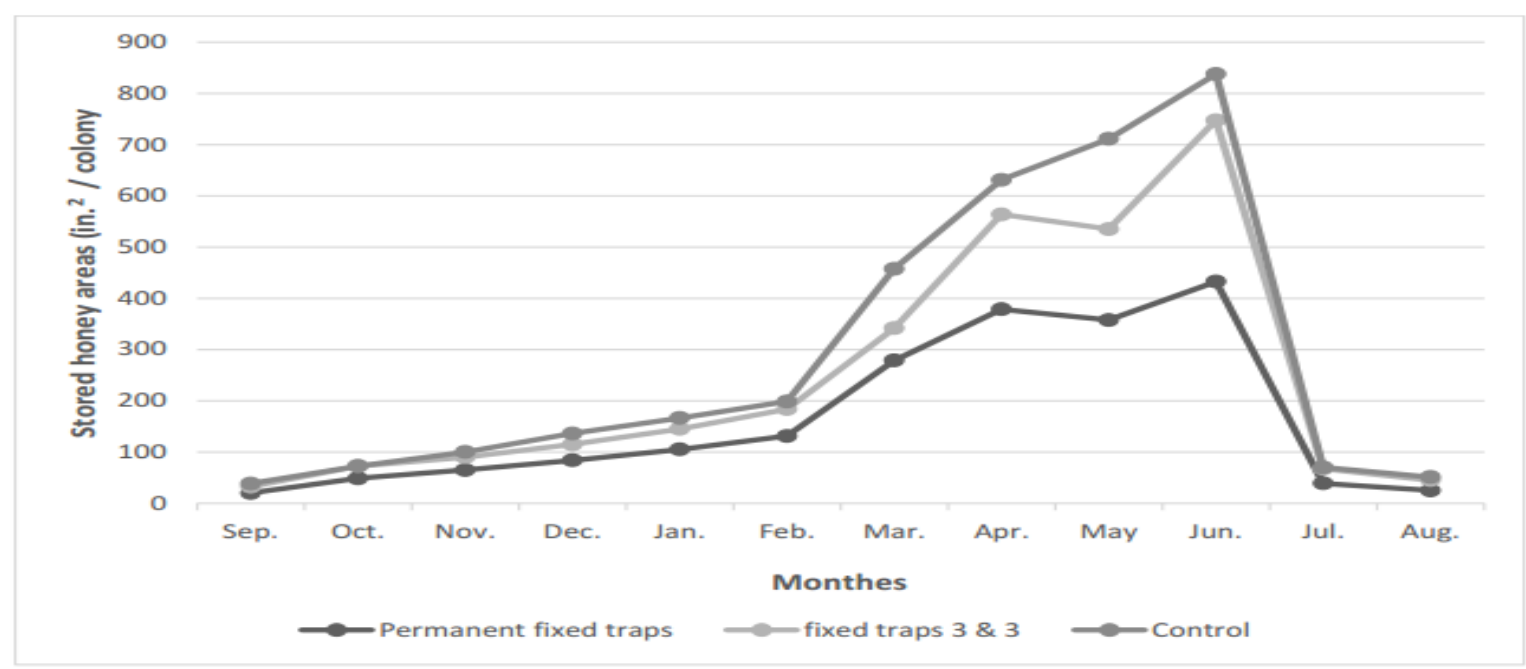

Fig 3. Monthly means of honey bee stored honey area (in. ${ }^{2}$ ) /colony established at Nasr city during season of (2013\&2014).

\section{References}

Abd-Al-Fattah, M.A. (1983). Some Ecological Studies of the Honeybee Colonies under the Environmental
Conditions of Giza Region. M.Sc. Thesis, Fac. Agric., Cairo Univ., 189 pp.

Abd Al-Hady, N.M.E. (2007).Studies on Some Activities of Honeybee Colonies under the 
Environmental Conditions of Damietta Region. M. Sc. Thesis. Fac. Agric., Cairo Univ., Egypt, 191pp.

Abdel-Rahman, M.F. (1998). Swarming of Honeybee Colonies (Apis mellifera L.) and Some Related Activities M. Sc. Thesis, Fac. Agric., Assiut Univ., 195 pp.

Abdel-Rahman, M.F. (2004). Comparative Studies Between the Characters of Some Races and Hybrids of Honeybee in Assiut Region, Upper Egypt. Ph. D. Thesis, Fac. Agric., Assiut Univ., 373pp.

Abou El-Enain, A.I. (2002).Genetic Studies on the Honeybee. Ph.D. Thesis, Fac. Agric. Alex. Univ., 197pp.

Chinh, T.X.; Boot, W.J and Sommeijer, M.J. (2005). Production of reproductive in the honeybee species Apis cerana in north Vietnam, J. Apc. Res., 44(2): 41-48

Duncan, D.B.(1955). Multiple range and multiple $F$ test. Biometrics, $11: 1-41$.

El-Feel, M.A. (2008). Studies on the Egyptian Honeybee Race (Apis mellifera L.)Cockerell in Siwa Oasis as A New Isolated Region. . M.SC. Thesis Faculty of Agric., Cairo Univ., 176 pp.

El-Wasseef, R.A.M. (2002).Ecological and Physiological Studies on Honeybee Colonies under Different Environmental Conditions. M. Sc. Thesis, Fac. Agric., Cairo Univ., 127pp.

Harbo, J.R. (1986).Effect of population size on brood production. Worker survival and honey gain in colonies of honeybees. J. Apic. Res., 25(1): 22-29.

Helal, R.M.; El- Dakhakhni, T.N.; Shawer, M.B. and Taha, E.A. (2003).Effect of moving the apiaries on activity of honeybee colonies. 1 -flight activity, gathering of nectar and sugar concentration contents and honey. J. Agric. Res., Tanta Univ., 29 (2): 268282.

Hussein, M. H. (1982). Effect of feeding on pollen collection of honeybee (Apis mellifera L.), in Assiut Governorate. Proc. Egypt's National Conf. Ent., Vol.
1: $83-92$.

Khattab, G.Y. (1976). Effect of ecological factors on honeybee Activities. M.Sc. Thesis, Fac. Agric., Cairo Univ., 198 pp.

Paxton, C.M. and Echagarreta, R. (1997).Comparative colony development of Africanized and European honeybee in (A.M) in low land neotropically. Yucatan, Mexico, J. Apic. Res., 2(36): 89-105.

Roman, A. (2006). Effect of pollen load size on the weight of pollen harvested from honey bee colonies (Apis mellifera L). Journal of apicultural science .50 (2):47-57.

Serag El-Dein, F.S.A. (1991).Nectar and pollen gathering activity of the honeybees. M.Sc. Thesis, Fac. Agric., Tanta Univ., 129pp.

Serag El-Dein, F.S.A. (2004). Comparative study on some products of Italian and Carniolan honeybee hybrids at Kafr El- Shaikh Governorate. J. Agric. Sc. Mansoura Univ., (1): 409 - 416.

Shaheen, A. A. (2012). Studies on Honeybee colonies Activities Under Environmental Conditions of North Sinai. M.Sc. Thesis, Fac. Agric. Cairo. Univ., 188pp.

Shawer, M.B., El-Dakakhni, N.M.; Helal, R.M. and Tana, E.A. (2003).Effect of moving the apiaries on activity of honeybee colonies. 1- Gathering and storing pollen, brood rearing and wax secretion. J. Agric. Res. Tanta Univ., 29 (2): 250 - 267.

Taha, E.K.A. (2005).Studies on honeybee (Apis mellifera L.). Ph. D. Thesis, Fac. Agric., Tanta Univ., $159 \mathrm{pp}$.

Zaref, E. (2008). Studies on Spread and Distribution of Pollen Grains Collected by Honeybees in North Sinai with Reference to Chemical Composition, Ph.D. Thesis, Fac. Agric. Suez Canal Univ., 170 pp.

Zeedan, E.W.M. (2002).Studies on Certain Factors Affecting Production and Quality of Queen Honeybees (Apis mellifera L.) in Giza region. M.Sc. Thesis, fac. Agric., Cairo Univ., 134pp. 


$$
\text { فعالية اختلاف فصول السنه على بعض انثطة نحل العسل تحت ظروف مدينة نصر - القاهرة - مصر. }
$$

أجريت هذه الدراسة فى منحل كلية الزراعة - جامعة الأزهر بمدينة نصر القاهرة خلال عام كامل (2014/2013م) واستخدمت فيه طوائف نحل كرينيولى هجين أول وقسمت الطوائف الى مجموعات, مجموعه ثبت على أبوابها مصائد حبوب لقاح طول مدة التجربة ومجموعة ثبت

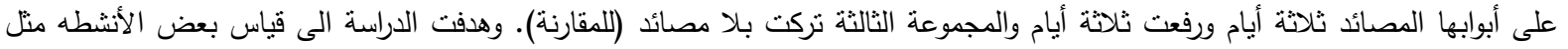

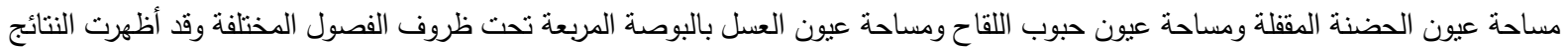

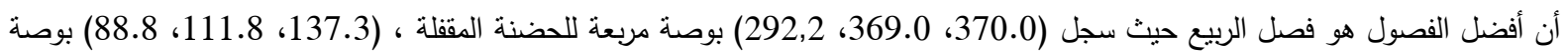
مربعة لدساحة عيون حبوب اللقاح ، (600.0، 480.2، 338.3) بوصة مربعة لعيون العسل وذللك لطوائف المقارنة والطوائف ذات مصائد الثلاثة

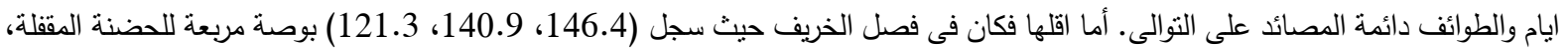

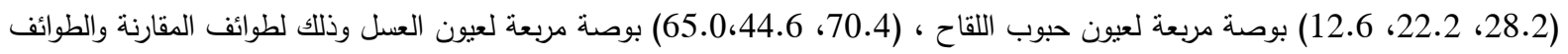
ذات مصائد الثلاثة ايام والطوائف دائمة المصائد على التوالى. أما فصل الثتاء والصيف فكانت قيمهما بين الربيع والخريف فى كل هذه الانثطة

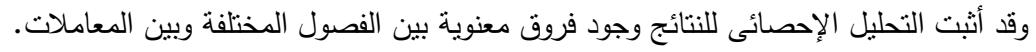

